\title{
High-resolution atmospheric reconstruction for Europe 1948-2012: coastDat2
}

\author{
B. Geyer \\ Institute of Coastal Research, Helmholtz-Zentrum Geesthacht, Geesthacht, Germany \\ Correspondence to: B. Geyer (beate.geyer@hzg.de) \\ Received: 5 November 2013 - Published in Earth Syst. Sci. Data Discuss.: 2 December 2013 \\ Revised: 20 March 2014 - Accepted: 25 March 2014 - Published: 17 April 2014
}

\begin{abstract}
The coastDat data sets were produced to give a consistent and homogeneous database mainly for assessing weather statistics and climate changes since 1948, e.g., in frequencies of extremes for Europe, especially in data sparse regions. A sequence of numerical models was employed to reconstruct all aspects of marine climate (such as storms, waves, surges, etc.) over many decades. The acronym coastDat stands for the set of consistent ocean and atmospheric data, where the atmospheric data where used as forcing for the reconstruction of the sea state. Here, we describe the atmospheric part of coastDat2 (Geyer and Rockel, 2013; doi:10.1594/WDCC/coastDat-2_COSMO-CLM). It consists of a regional climate reconstruction for the entire European continent, including the Baltic Sea and North Sea and parts of the Atlantic. The simulation was done for 1948 to 2012 with the regional climate model COSMO-CLM (CCLM) and a horizontal grid size of 0.22 degree in rotated coordinates. Global reanalysis data of NCEP1 were used as forcing and spectral nudging was applied. To meet the demands on the coastDat data set about 70 variables are stored hourly.
\end{abstract}

\section{Motivation}

The precursor of coastDat2, coastDat1 (Weisse et al., 2009), was widely used. About $50 \%$ of the coastDat 1 users were commercial, while $25 \%$ were academic and another $25 \%$ were from the authorities. Applications range from assessing long-term variability and change to risk assessment and design, for example of offshore wind farms. As coastDat1 terminated in 2007, and as there were strong requests for an upgrade comprising the most recent years at higher spatial resolution, the coastDat 2 effort was implemented. The atmospheric part of coastDat2 described in this paper was produced with the community model COSMO-CLM on the current super computer of the German Climate Computing Center (DKRZ). It is the successor of the coastDat1 regional atmospheric simulation done with REMO5.0 (Feser et al., 2001; Jacob et al., 2001). For coastal areas the higher resolution is the main advantage. The overall advantage is the availability of the last 5 years.

\section{Model setup}

For the reconstruction the COSMO model in CLimate Mode (COSMO-CLM) version 4.8_clm_11 (Rockel et al., 2008; Baldauf et al., 2011; Steppeler et al., 2003) was used. The COSMO model is the non-hydrostatic operational weather prediction model applied and further developed by the national weather services affiliated in the COnsortium for SMall-scale MOdeling (COSMO). The climate mode is applied and developed by the Climate Limitedarea Modelling Community (http://www.clm-community. eu). The use of the model is well supported by the members of the community and documented mainly via the COSMO documentation (http://www.cosmo-model.org/ content/model/documentation/core/default.htm).

The simulation was done on a regular grid in rotated coordinates with a rotated pole at $170.0^{\circ} \mathrm{W}$ and $35.0^{\circ} \mathrm{N}$ with a resolution of $0.22^{\circ}$, a time step of $150 \mathrm{~s}$ and hourly output. Figure 1 presents the model domain; 40 vertical levels up to $27.2 \mathrm{~km}$ height and 10 soil levels down to $11.5 \mathrm{~m}$ depth were used. Spectral nudging after von Storch et al. (2000) was applied for large-scale wind speed components in the 


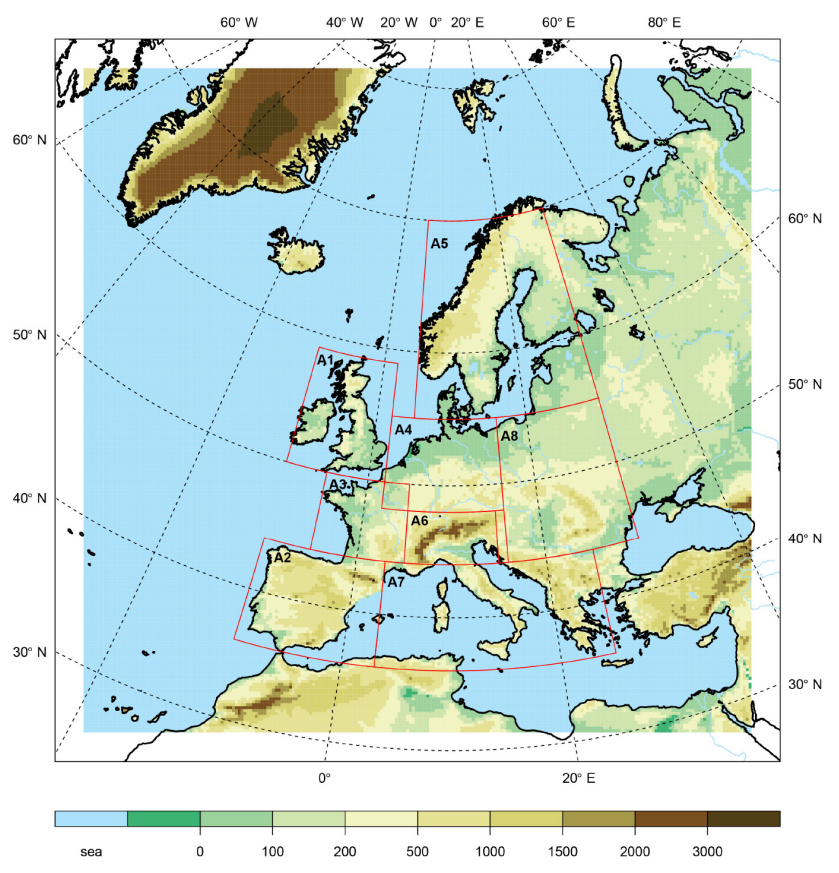

Figure 1. Orography [m] of model domain of cpastDat2-CCLM (colored area). The white frame indicates the 10 pixel wide sponge zone. The red boxes define the borders of the eight European standard evaluation domains defined by Rockel and Woth (2007).

upper levels (above $850 \mathrm{hPa}$ ) to enforce the observed largescale circulation. Every fifth time step, in both directions, the information of the five largest wavelengths was nudged with a nudging factor of 0.5 . A detailed description of the technique was provided by Müller (2003, p. 50). At the lateral boundaries the relaxation scheme by Davies (1976) was applied. The affected 10 grid boxes, the sponge zone, are cut off for all time series data of the set.

Meteorological initial and boundary conditions were taken from the 6 hourly NCEP1 reanalysis data (Kalnay et al., 1996; Kistler et al., 2001). The simulation was initialized on first of January 1948 with interpolated fields for the air temperature, zonal and meridional wind component, specific water vapor content, specific cloud water content, surface specific humidity, skin temperature for sea points, thickness of surface snow amount and volume fraction of soil moisture. The interpolation to the coastDat2-CCLM grid was done by the model chain part int21m v1.9_clm5 (Schättler, 2011). The soil moisture values of the coarse NCEP grid require more spin up time than the few days required by atmospheric fields (Denis et al., 2002). Therefore it is necessary to run the model for a certain time and to restart with the gained soil moisture fields. Figure 2 shows the development of the moisture for area means of layers 1-8 for the European standard evaluation areas (Rockel and Woth, 2007) adopted by Christensen and Christensen $(2007$, p. 22). The layers 9-10 are hydrologically not active, the water draining through layer 8 was

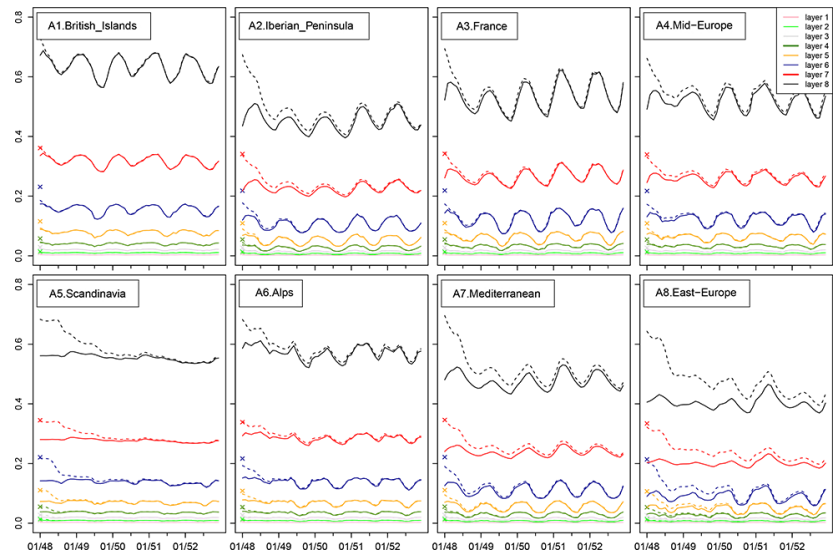

Figure 2. Soil moisture content [m] for the eight European subregions of Fig. 1. Crosses: initial value; dashed lines: monthly mean of spin up run; solid: monthly mean of the final (restarted) simulation. The colors belong to the soil levels.

added to the runoff. Layer 7 and 8 have the same start value of $0.33 \mathrm{~m}$. The end of the spin up period is where both soil moisture fields (soil moisture content of spin up simulation and soil moisture content of coastDat2-CCLM) converge. The required time depends on the accuracyof the initial condition and therefore differs between the regions. The largest spin up time of 5 years can be found for eastern Europe. Therefore we choose 1948-1952 as spin up time and restarted the coastDat2-CCLM simulation on the first of January 1948 as before with the same initial conditions except for soil moisture, where we used the gained values from the spin up simulation.

Land surface processes were parameterized with the TERRA-ML scheme (Schrodin and Heise, 2001; Doms et al., 2011). For sea points the NCEP1 skin temperatures were used as lower boundary condition. Cumulus convection was parameterized using the Tiedtke scheme (Tiedtke, 1989). Clouds were determined by the prognostic variables cloud water and cloud ice. We used a fifth order Runge-Kutta time integration scheme.

The hourly output was written in netCDF following the CF-conventions 1.4 (Eaton et al., 2009). In the appendix (Table A1) all output variables are listed.

\section{External data}

Beside the meteorological lateral boundary conditions information on climatologically constant data has to be prescribed in the model: the surface height and orographic roughness length were taken from the gtopo30 data set of the Distributed Active Archive Center (US Geological Survey, 2004), the land-sea fraction, parameters of vegetation, leaf area, and root depth from the Global Ecosystems V2.0. The soil type was taken from the Food and Agriculture Organization of the United Nations (FAO). The climatological deep 

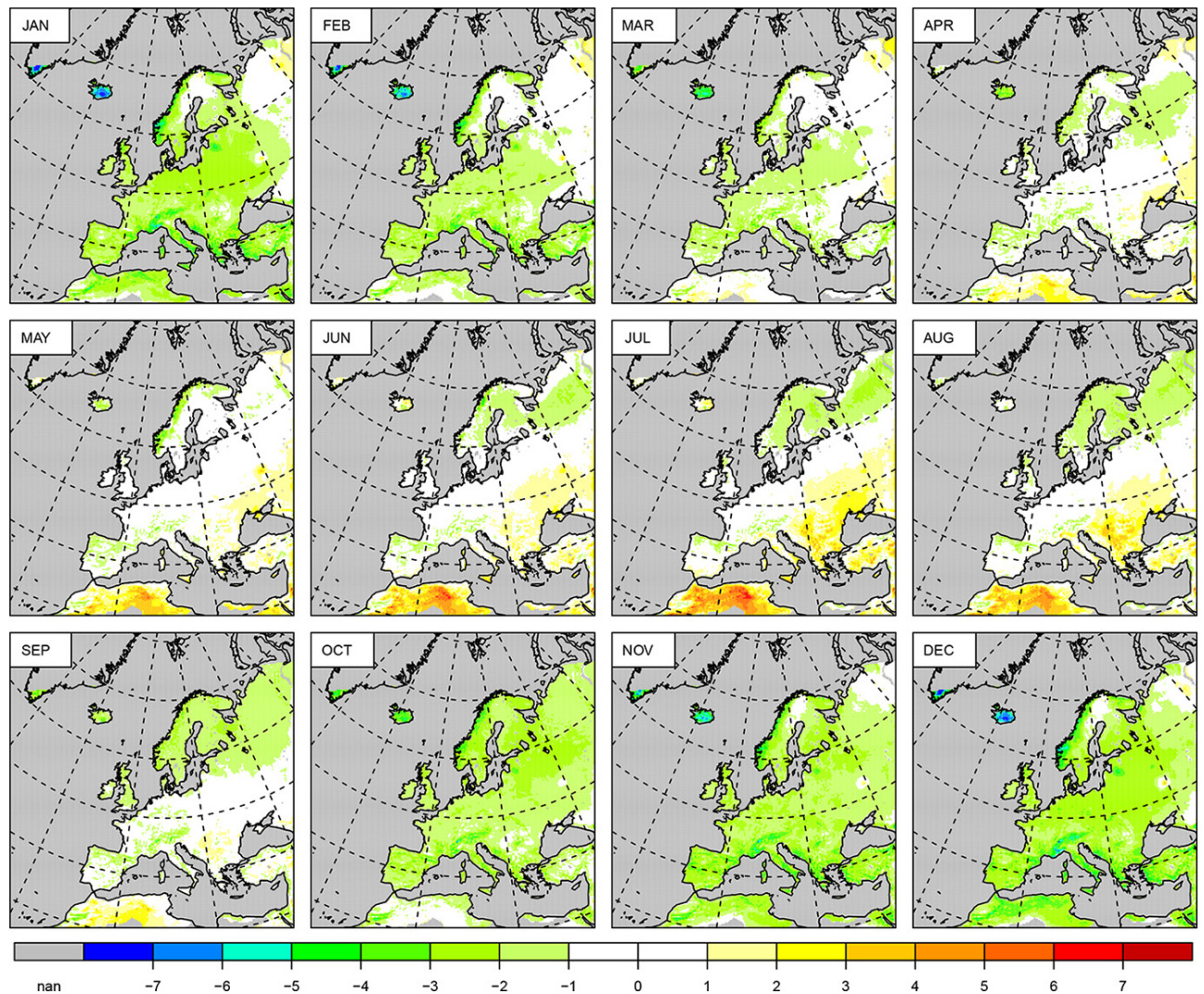

nan
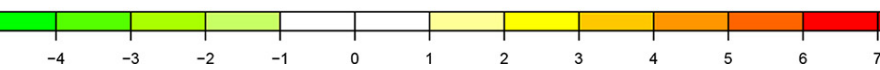

Figure 3. Mean differences of monthly mean $2 \mathrm{~m}$ air temperatures [K] from 1950 to 2012: coastDat2-CCLM minus E-OBS8.0.

soil temperature was taken from the CRU (Climate research Unit at the University of East Anglia). To generate a file with the merged information on the model grid, the so-called PrEProcessor (PEP) was used. Detailed information on the data as well as the preprocessor is given by Smiatek et al. (2008). The list of used climatological input variables are included in Table A1.

\section{Evaluation}

The evaluation was done for several parameters. The user demands are manifold, ranging from coastDat-internal forcing for the wave model via air chemistry models to research in the field of wind energy. In this paper we show data set comparisons for the most user-requested quantities: $2 \mathrm{~m}$ temperature, total precipitation, wind speed, cloud cover, and height of boundary layer.

\subsection{Reference data sets}

The evaluation of the data set for air temperature, precipitation, wind, and cloud cover was done by using common gridded data sets: E-OBS of the ENSEMBLES project version 8.0 (van den Besselaar et al., 2011; Haylock et al., 2008), CRU version ts_3.2 (Jones and Harris, 2011), GPCC
(Global Precipitation Climatology Centre), version 6 (Rudolf et al., 2010), and REGNIE from Deutscher Wetterdienst (Dietzer, 2000). For comparison of the height of boundary layer we used station data for Lindenberg, Germany (Beyrich and Leps, 2012).

\subsection{Near-surface air temperature}

Figure 3 shows the mean differences between the monthly means of air temperature at $2 \mathrm{~m}$ height of coastDat2-CCLM and E-OBS8.0 for 1950-2012. The E-OBS data were interpolated to the rotated grid of CCLM.

From April to September, the differences are between $-1{ }^{\circ} \mathrm{C}$ and $1{ }^{\circ} \mathrm{C}$ for wide areas of mid-Europe. High differences with values up to -6 and $+6^{\circ} \mathrm{C}$ occur over Iceland (in winter) and North Africa (in summer), respectively. After Einarsson (1984), the highest Icelandic climatological station is at Hveravellir at $642 \mathrm{~m}$ - the CCLM model orography reaches to $1560 \mathrm{~m}$ around Vatnajökull. This can be a reason for the huge deviation between model and gridded observation. Similar to Bromwich et al. (2005), who were using Polar-MM5 for their $8 \mathrm{~km}$ resolution Iceland simulation, we have mean January $2 \mathrm{~m}$ temperatures for 1991-2000 of $-12{ }^{\circ} \mathrm{C}$. Bromwich found a cold bias of up to $1 \mathrm{~K}$ during winter in the northern part of Iceland in his simulations. 

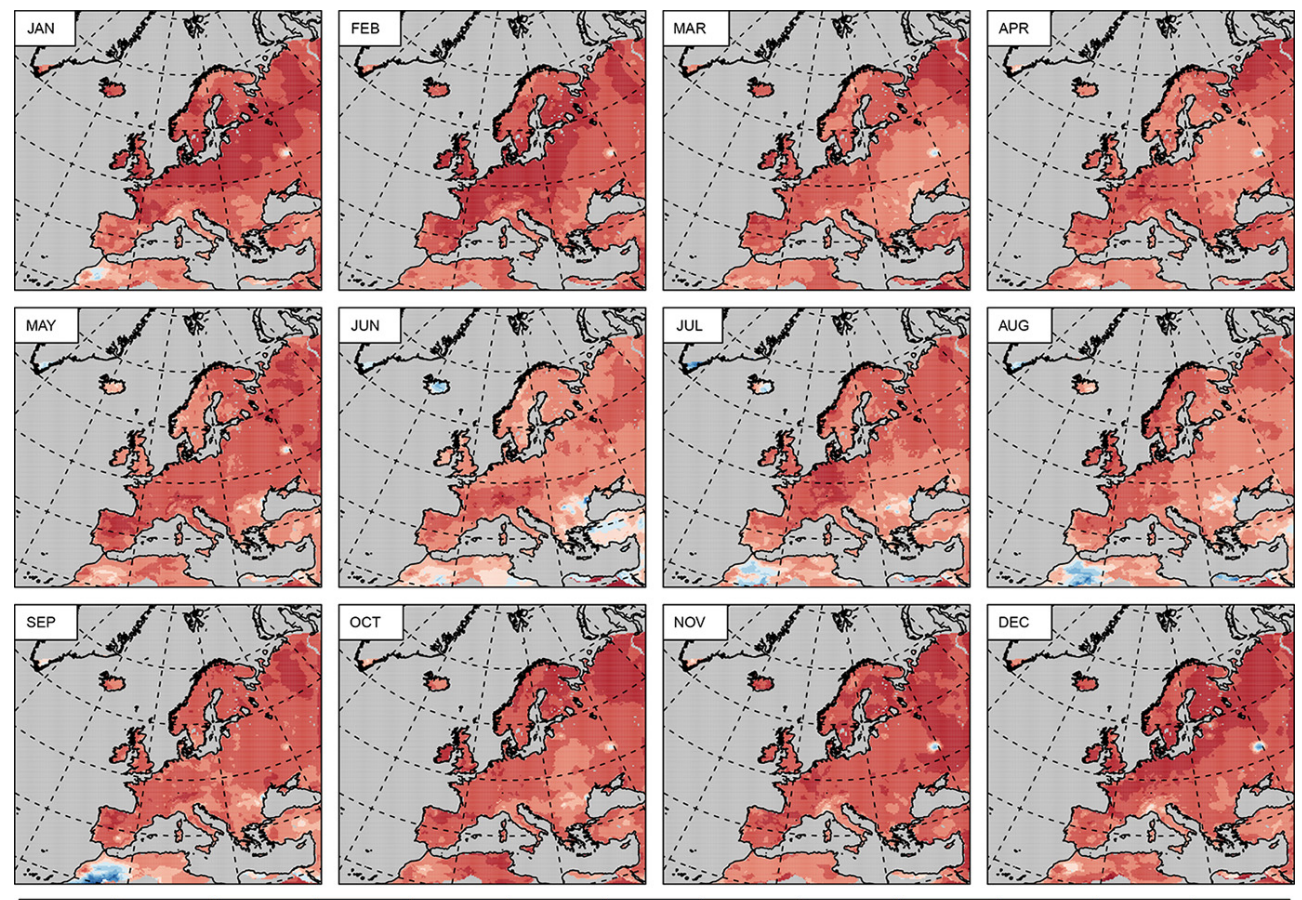

nan
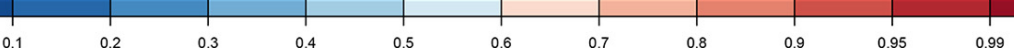

Figure 4. Correlations between coastDat2-CCLM and E-OBS8.0 of monthly mean $2 \mathrm{~m}$ air temperatures from 1950 to 2012.
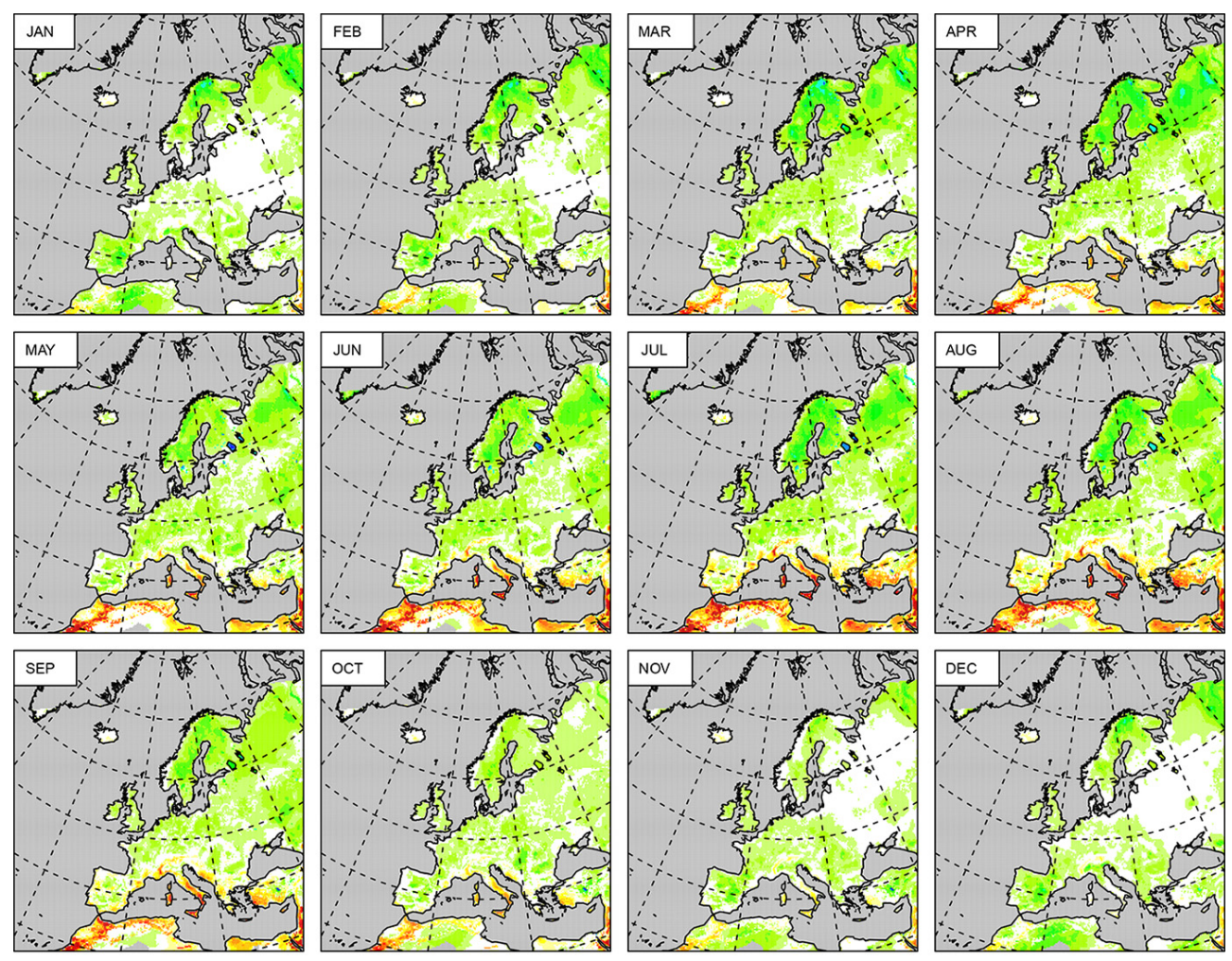

nan

Figure 5. Differences of mean diurnal temperature range [K] from 1950 to 2012: coastDat2-CCLM minus E-OBS8.0. 

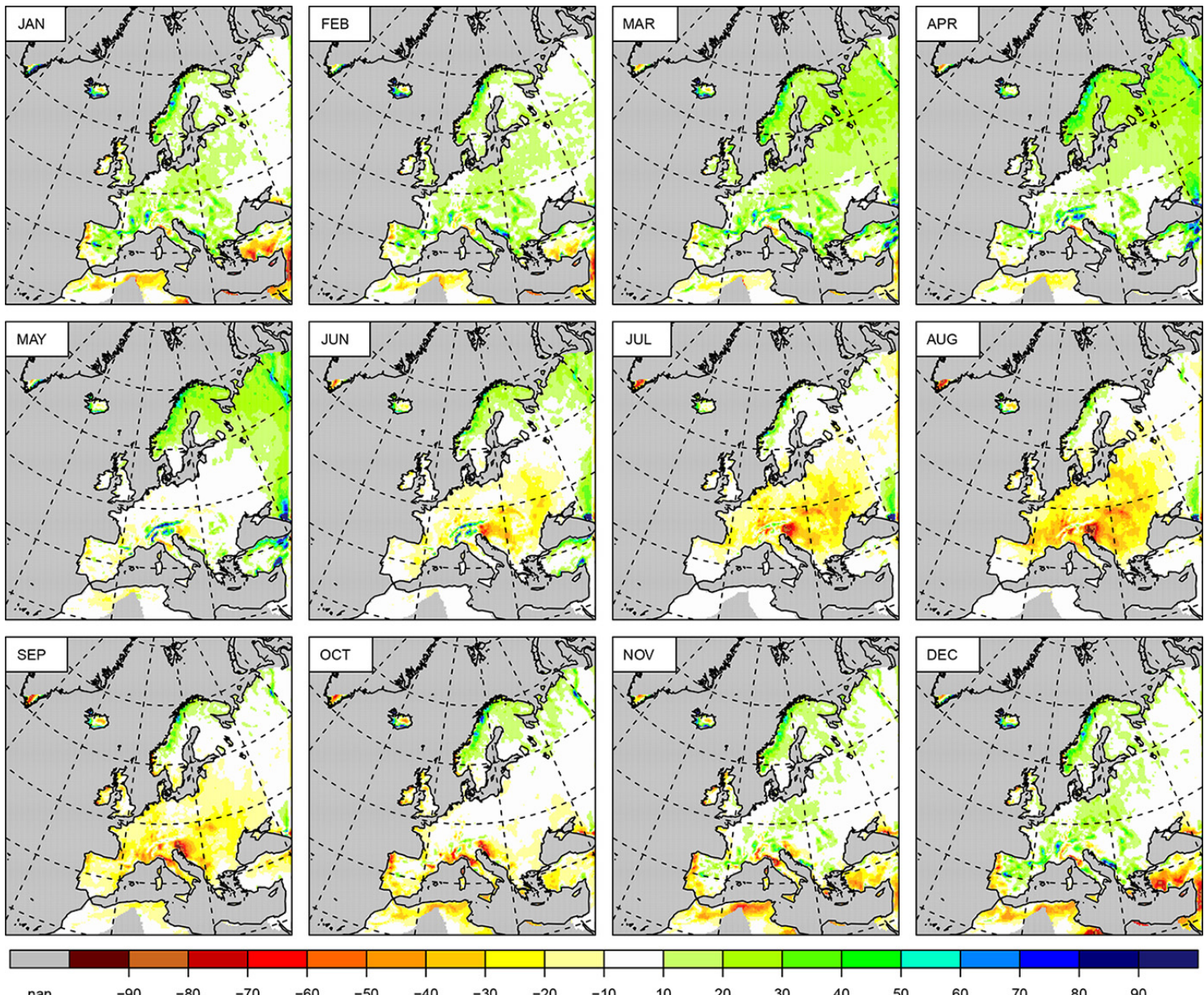

nan

$-90$
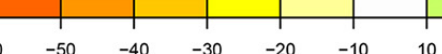

Figure 6. Differences of mean monthly sums of total precipitation [mm] from 1950 to 2012: coastDat2-CCLM minus E-OBS8.0.

For Africa Kothe et al. (2014) found that the used albedo values are to low compared to satellite data (Kothe et al., 2014, Fig. 2), which leads to higher temperatures in summer. At the time when the coastDat2-CCLM simulation was started the new albedo data set was not yet available. The statistical significance on the $0.05 \%$ level of the $2 \mathrm{~m}$ temperature differences was tested separately for 12 month to avoid auto correlation. It yields for large regions statistically significant values between observation and CCLM simulation. This result is, however, not surprising because of inherent model biases of the forcing NCEP1 data. To give an additional hint on the quality of the time series in Fig. 4, the correlations between CCLM and E-OBS8.0 are shown. Here the correlations are over large areas statistically significant and coastDat2-CCLM represents a large part of the observed variance.

The precursor data set, coastDat1, was used as forcing for biosphere models (e.g., (Jung et al., 2007) or (Vetter et al., 2008)), where the diurnal cycle has major importance. Therefore, we determined the differences of the diurnal temperature range. It was calculated as the difference between daily maximum $2 \mathrm{~m}$ air temperature and daily minimum $2 \mathrm{~m}$ air temperature. The means of the monthly mean differences between coastDat2-CCLM and E-OBS8.0 for the period 1950-2012 are shown in Fig. 5.

There is a tendency to underestimate the diurnal temperature range for wide areas all over the year, except for the part of North Africa contained in the model domain. The differences in the maximum $2 \mathrm{~m}$ air temperature are highest for April-August. In the North African part the coastDat2CCLM temperatures are several degrees higher than the values of E-OBS and in the northeastern parts of Europe they are several degrees lower than the observations (not shown). The differences between the two data sets in minimum $2 \mathrm{~m}$ air temperature are much smaller, with the highest deviations occurring for Africa from June to August (not shown). The main source for the differences in the diurnal temperature range is the difference in maximum $2 \mathrm{~m}$ air temperature.

\subsection{Precipitation}

Figure 6 shows the mean differences between the monthly sums of total precipitation of coastDat2-CCLM and 
Table 1. Seasonal-mean minimal differences of precipitation [\%] over land between coastDat2-CCLM and the ensemble of the three observational data (E-OBS, CRU, GPCC) for 1950-2010 and the eight European sub-regions of Fig. 1: British Islands (A1), Iberian Peninsula (A2), France (A3), mid-Europe (A4), Scandinavia (A5), Alps (A6), Mediterranean (A7), eastern Europe (A8). Values less than 10\% are printed bold.

\begin{tabular}{lrrrrrrrr}
\hline & A1 & A2 & A3 & A4 & A5 & A6 & A7 & A8 \\
\hline DJF & $\mathbf{- 1 . 2}$ & $\mathbf{3 . 9}$ & $\mathbf{6 . 4}$ & 15 & 20 & $\mathbf{7 . 8}$ & $-\mathbf{0 . 3}$ & 24 \\
MAM & $\mathbf{2 . 1}$ & $\mathbf{0 . 2}$ & $\mathbf{1 . 1}$ & $\mathbf{7 . 7}$ & 43 & $\mathbf{9 . 5}$ & $\mathbf{- 1 . 8}$ & 11 \\
JJA & $\mathbf{- 9 . 6}$ & -34 & -29 & -23 & $\mathbf{2 . 1}$ & -17 & -42 & -33 \\
SON & $\mathbf{- 9 . 4}$ & -17 & -14 & $-\mathbf{6 . 7}$ & $\mathbf{7 . 0}$ & -14 & -23 & -16 \\
\hline
\end{tabular}
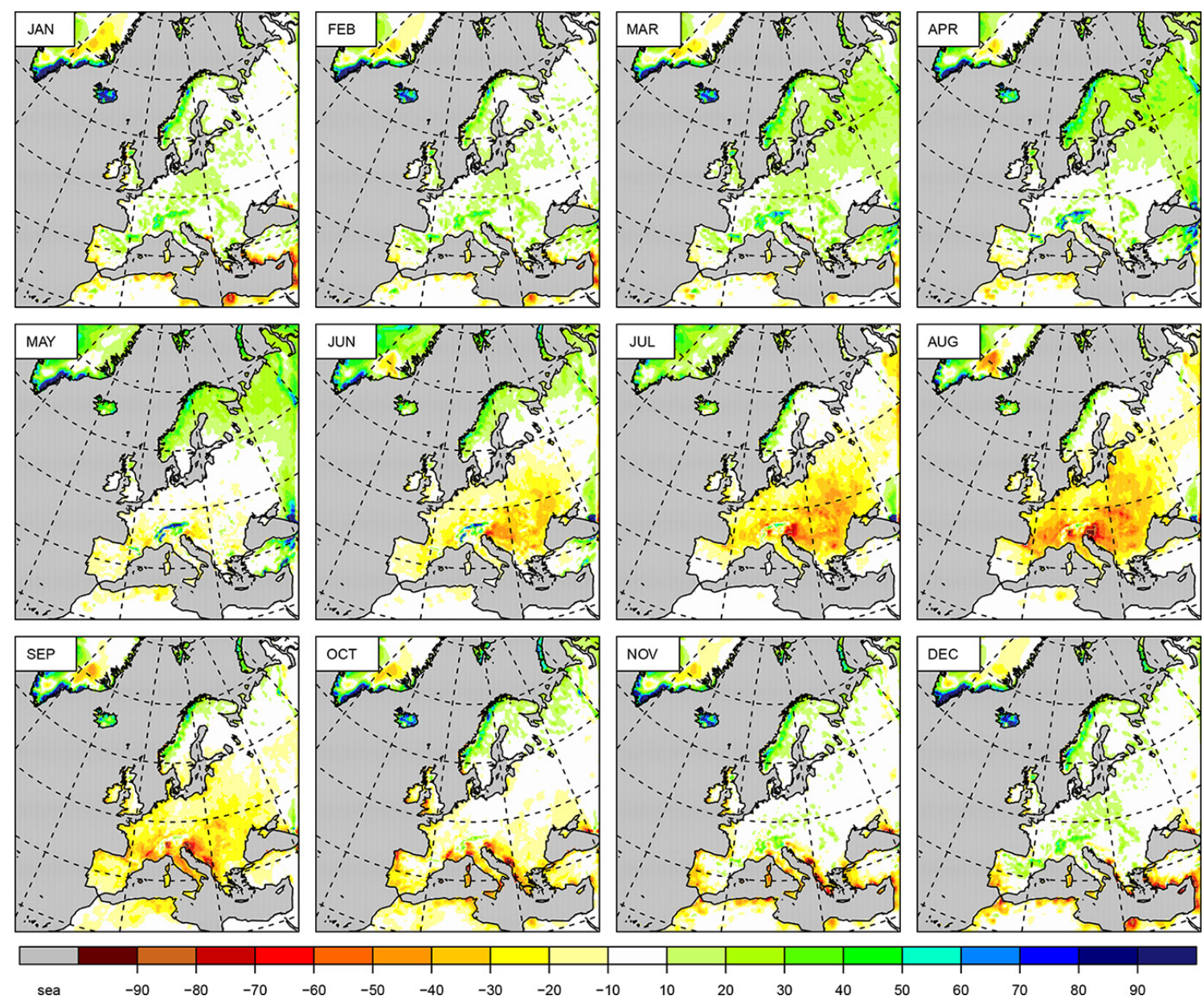

Figure 7. Differences of mean monthly sums of total precipitation [mm] from 1950 to 2010: coastDat2-CCLM minus GPCC6.

E-OBS8.0. The basis is the period 1950-2012, the E-OBS data are interpolated to the rotated grid of CCLM. Main deviations occur on the one hand in spring over Scandinavia and the northeastern part of the model domain, with more simulated precipitation than E-OBS reconstructed. On the other hand, we have less precipitation in southeastern Europe in summer. The tendency to precipitation values higher than E-OBS8.0 in Northern Europe is stronger and occurs over the entire year in the precursor atmospheric simulation with REMO-SN (belonging to coastDat1) as well as the lower val- ues in July to September in southern part of mid-Europe (not shown).

To give a hint which patterns of differences depend on the choice of the gridded observational data set, we added the plot of mean differences between the monthly sums of total precipitation of CCLM and GPCC6 (Fig. 7). The basis is the period 1950-2010, the GPCC data are interpolated to the rotated grid of CCLM. The lower summer values for southeastern Europe are more pronounced in this comparison than in the comparison with E-OBS8.0, as 
Area mean monthly precipitation: DJF
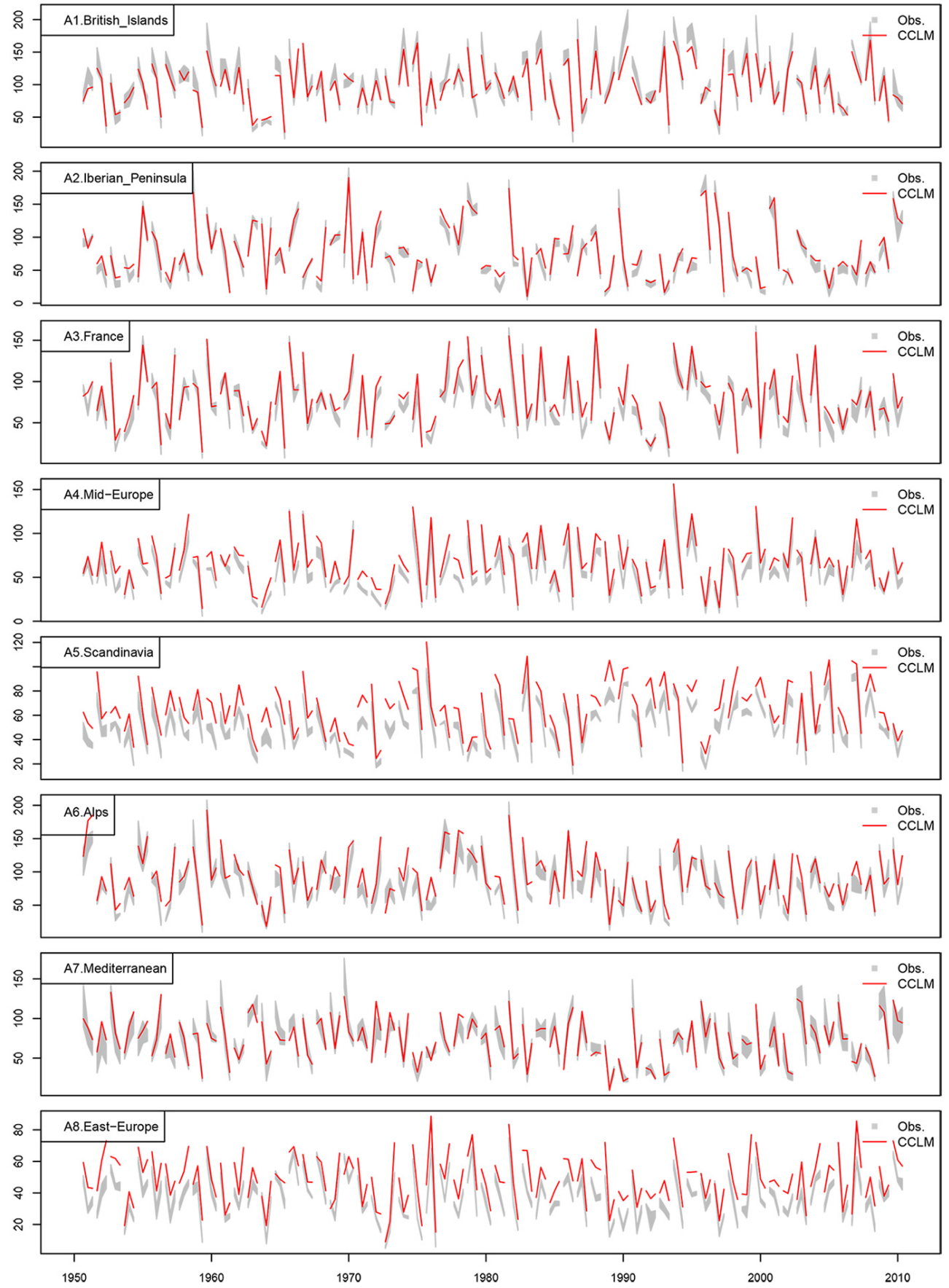

Figure 8a. Area mean monthly sums of total precipitation of December, January, and February of 1950-2010: coastDat2-CCLM (red), range of GPCC6, E-OBS8.0 and CRU3.2 for each season (gray filled).

GPCC6 shows 5-10 mm higher monthly summer precipitation in eastern Europe (not shown). Strong deviations between GPCC6 and E-OBS8.0 occur for Iceland from October to April and Turkey from December to February, with up to $100 \mathrm{~mm} \mathrm{month}^{-1}$ and up to $60 \mathrm{~mm} \mathrm{month}^{-1}$, respec- tively, more precipitation in E-OBS8.0. Less precipitation is indicated in E-OBS8.0 with 60 to $100 \mathrm{~mm} \mathrm{month}^{-1}$ in winter for Sistema Central and Adriatic coast respectively. For November to April the Alpine precipitation deviates with up to $100 \mathrm{~mm} \mathrm{month}^{-1}$ more precipitation in E-OBS8.0. 
Area mean monthly precipitation: MAM
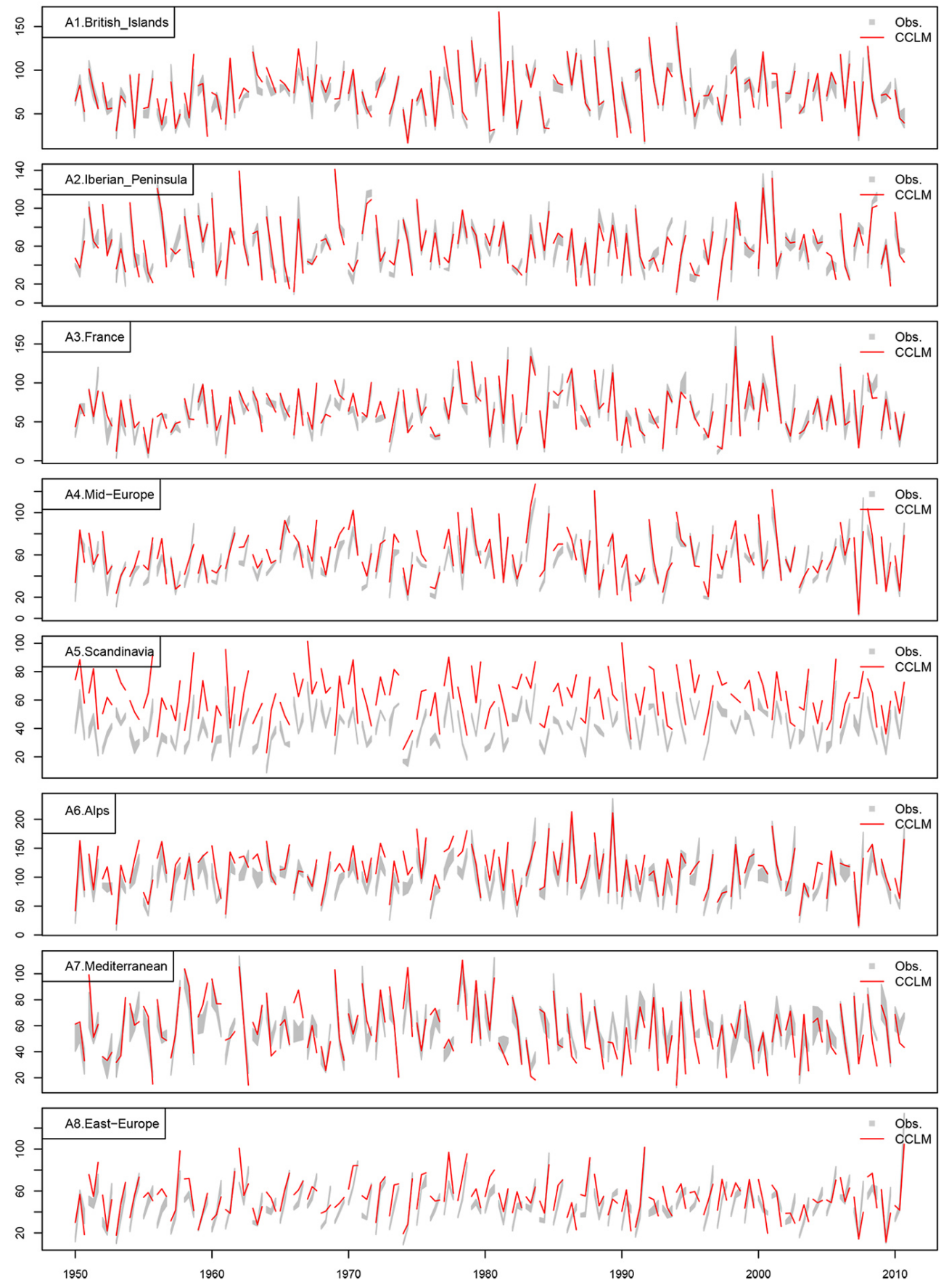

Figure 8b. Area mean monthly sums of total precipitation of March, April, and May of 1950-2010: coastDat2-CCLM (red), range of GPCC6, E-OBS8.0 and CRU3.2 for each season (gray filled).

To use the information on the spread of the data sets based on observations (E-OBS, GPCC and CRU), we calculated the mean minimal differences between coastDat2-CCLM and the three observational data sets and listed them as percentages in Table 1.
To summarize the results, we find especially good agreement for December-May for the British Islands (A1), Iberian Peninsula (A2), France (A3), the Alps (A6) and Mediterranean (A7); deviations are below $10 \%$ of mean observational value. The main systematic negative deviations occur 
Area mean monthly precipitation: JJA
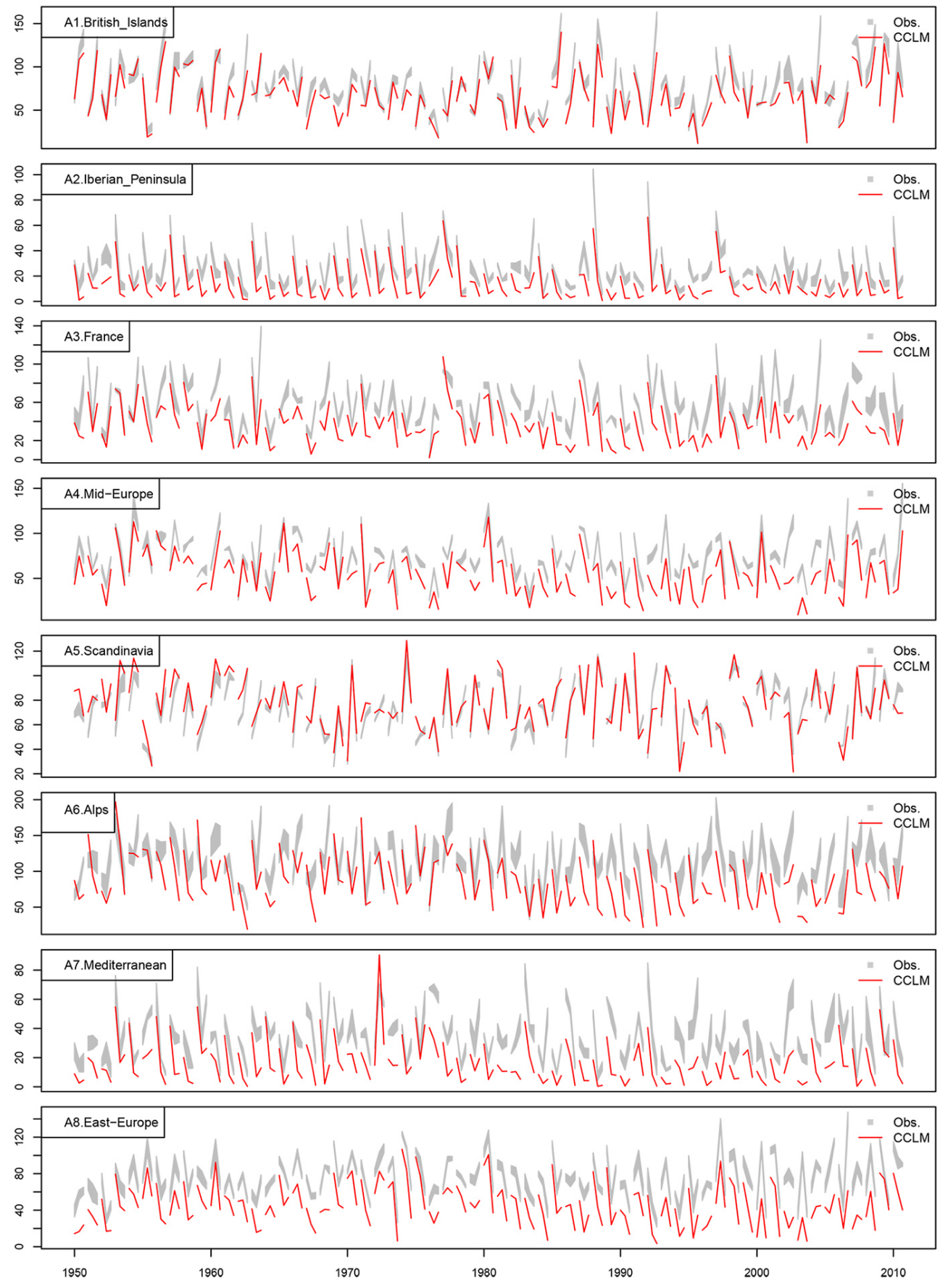

Figure 8c. Area mean monthly sums of total precipitation of June, July, and August of 1950-2010: coastDat2-CCLM (red), range of GPCC6, E-OBS8.0 and CRU3.2 for each season (gray filled).

from June to August for the Iberian Peninsula (A2), June to November for Mediterranean (A7) and June to August in eastern Europe (A8), while systematic highest positive deviations are found from December to May in Scandinavia (A5). In addition to the table, we show the monthly mean time series of the eight regions for coastDat2-CCLM and for the range of all the three observational data sets. The months are sorted by season in Fig. 8a-d. Each season of each year consist of a red line from CCLM-values and a gray area for the range of the three monthly mean observational values. As 
Area mean monthly precipitation: SON
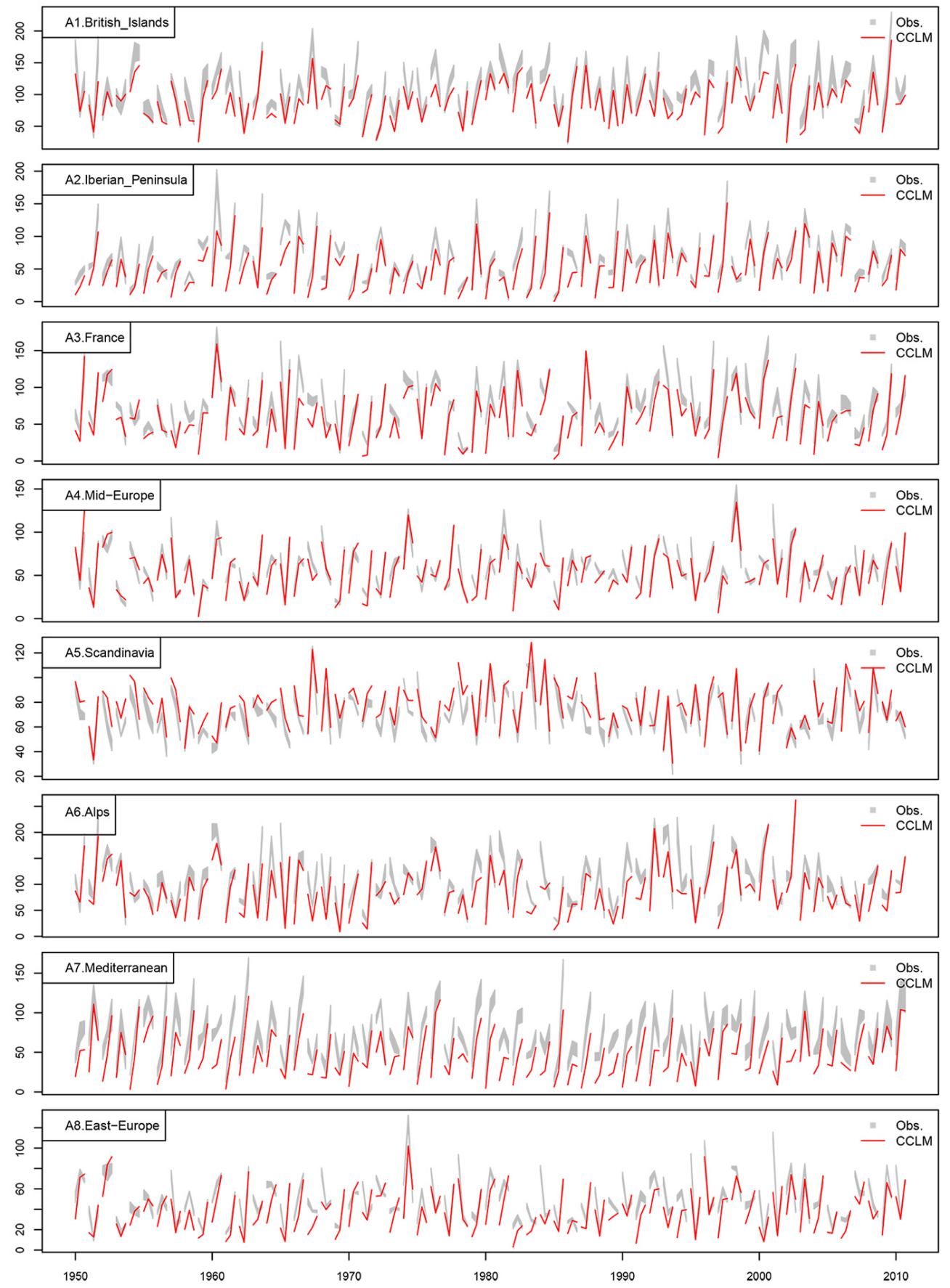

Figure 8d. Area mean monthly sums of total precipitation of September, October, and November of 1950-2010: coastDat2-CCLM (red), range of GPCC6, E-OBS8.0 and CRU3.2 for each season (gray filled).

some users of our data set are interested in especially dry or wet seasons, we show absolute values. It becomes clear, that the deviations between the observational data sets are huge (e.g., for Mediterranean from June to November or the Alps in summer). But nevertheless the model mean is outside the gridded observational data set range in various cases.

The REGNIE data set has a very high spatial resolution of $1 \mathrm{~km}$ grid spacing covering the entire geopraphic region of Germany. As the data are daily resolved we have the 


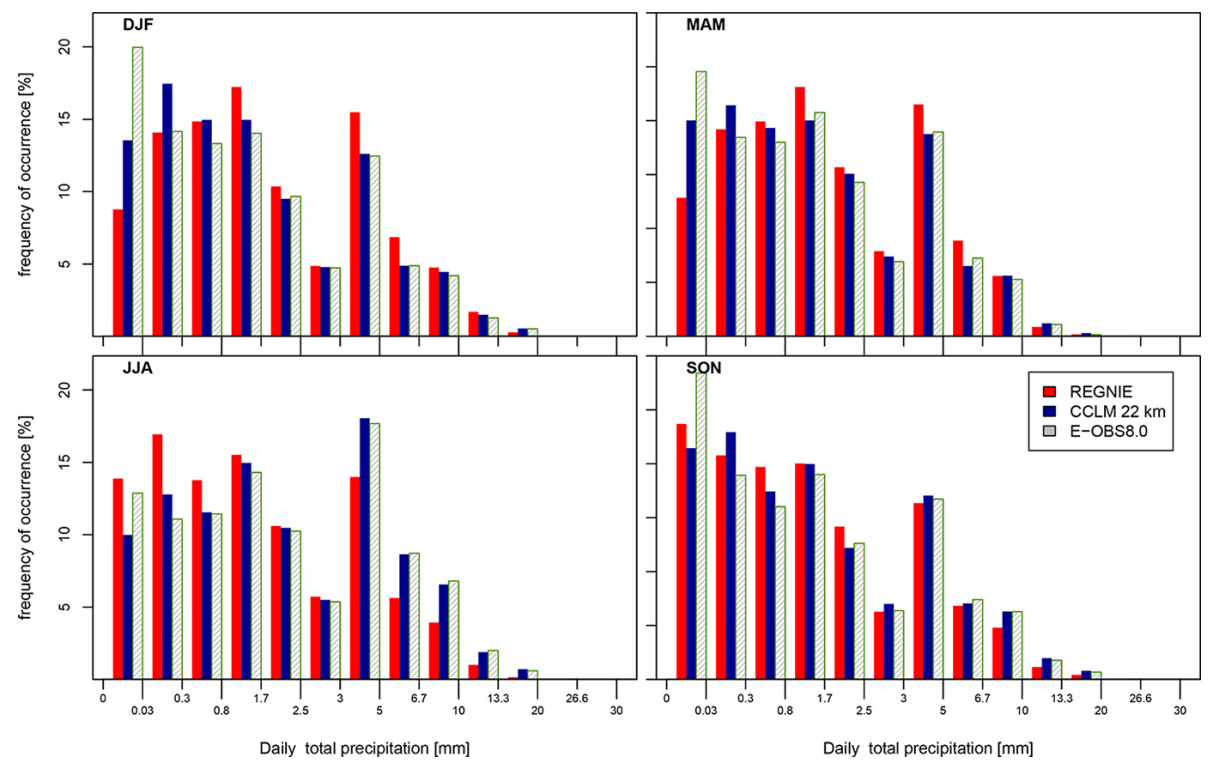

Figure 9. Histogram of Germany mean daily precipitation sums [mm] from 1951 to 2009: REGNIE (red bars), coastDat2-CCLM (blue bars), and E-OBS8.0 (shaded).The frequency is given in \%.
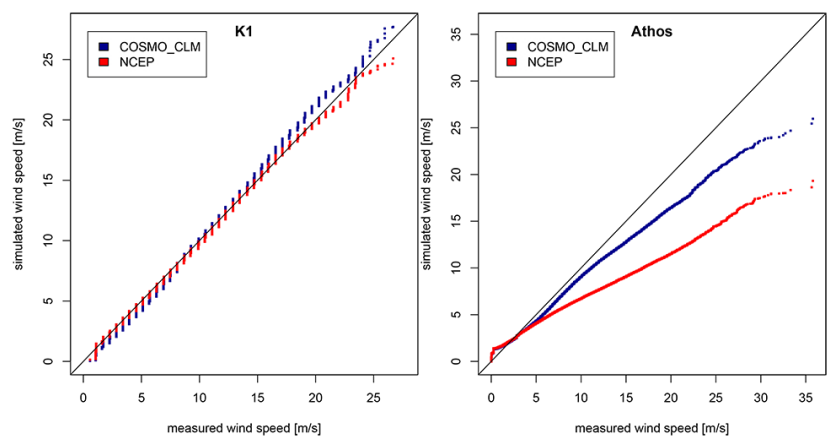

Figure 10. Validation of near-surface wind speeds: quantilequantile plot for Atlantic offshore conditions (left: 2007-2012, platform K1 height corrected) and near-shore Mediterranean conditions (right: 2000-2012, buoy Athos).

possibility of statistics on a daily basis. Figure 9 shows a histogram of area mean daily precipitation for Germany. The borders of the classes were chosen following the recommendation of the Global Precipitation Climatology Project.

The shape of the REGNIE distribution function is generally well reproduced in coastDat2-CCLM. However, only for the two classes from 1.7 to $3 \mathrm{~mm} \mathrm{day}^{-1}$ for all seasons the three data sets (REGNIE, coastDat2-CCLM and E-OBS8.0) show the same frequencies. For all other classes no consistent statement concerning relation between the data sets is possible.

\subsection{Wind}

The modified Brier skill score was calculated following Winterfeldt et al. (2010). They found an added value of the regional atmospheric simulation of coastDat1, done with REMO5.0, compared to the forcing reanalysis of NCEP with satellite data of quikScat near the coasts. These findings were reproduced for the coastDat2-CCLM data set. Important for users of our wind data is the proofed good offshore quality of the surface wind data, although the Brier skill score for wide offshore fields is negative, meaning that NCEP1 data has a higher agreement with observations than coastDat2CCLM. As shown for the precursor data set, coastDat1, by Sotillo et al. (2005, Fig. 7), the quality (e.g., at platform K1) is very good. Following the idea of Sotillo et al., our Fig. 10 shows the quantile-quantile plot of observation vs. model data (blue coastDat2-CCLM and red NCEP1). On the left hand side, results are for Atlantic buoy K1 (at $48.701^{\circ} \mathrm{N}$, $12.401^{\circ} \mathrm{W}$ ) and on the right hand side for Aegean Buoy Athos (at $39.97^{\circ} \mathrm{N}, 24.72^{\circ} \mathrm{E}$ ). $\mathrm{K} 1$ observations were interpolated from anemometer height of $3 \mathrm{~m}$ to $10 \mathrm{~m}$. A logarithmic wind profile was assumed, and the roughness length was calculated with the Charnock relation depending on the wind speed (Stull, 1988). The NCEP1 data were linearly interpolated in time to hourly values. For the Mediterranean buoy Athos NCEP1 data were interpolated to the measurement output interval of $3 \mathrm{~h}$. The quality of the wind fields from coastDat 1 and coastDat 2 is comparable with the tendency of better representation of high wind speeds in coastDat2. 

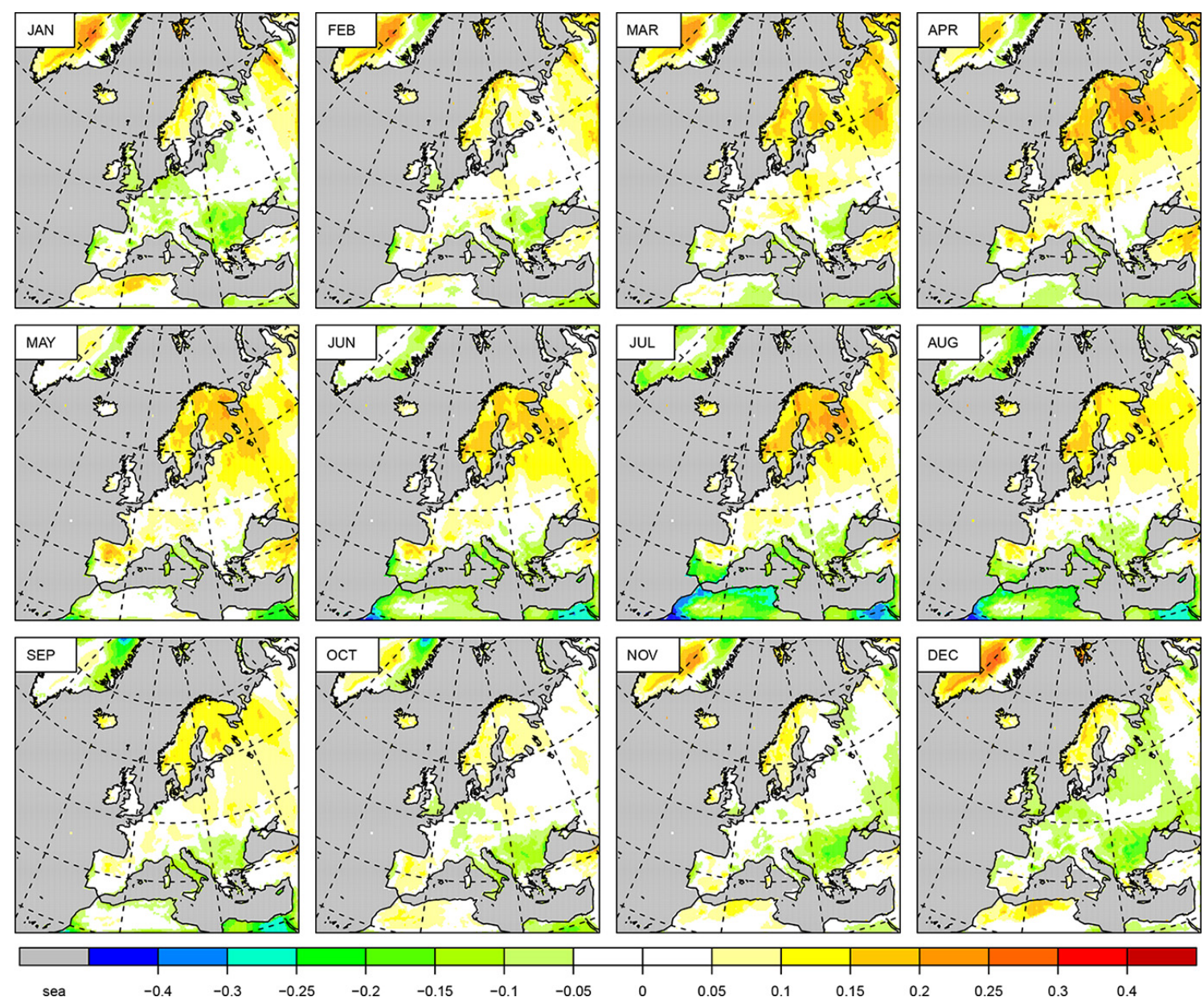

sea

$-0.4$
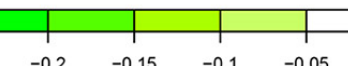

1

0.05

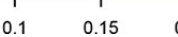

$\begin{array}{llll}0.2 & 0.25 & 0.3 & 0.4\end{array}$

Figure 11. Differences of mean monthly means of total cloud cover [1] from 1950 to 2010: coastDat2-CCLM minus CRU3.2.

\subsection{Total Cloud Cover}

The comparison of the total cloud cover of coastDat2-CCLM and CRU data is shown in Fig. 11. For most of the months and most of the areas the differences are below $10 \%$. The highest differences occur from June to August over North Africa and March to August over Scandinavia. For most of the year, the differences for Greenland are high.

\subsection{Height of planetary boundary layer}

Observational data for the height of the boundary layer are hardly available. As this variable is especially important when the coastDat data set is used for air chemistry applications (i.e., to simulate the transport of harmful substances), we show at least a comparison for a short-term period (2003-2012) at a single station (Lindenberg, WMO no. $10393,52.21^{\circ} \mathrm{N}, 14.10^{\circ} \mathrm{E}$ ). As the height of the boundary layer shows a strong diurnal cycle, the data set was divided into four sets depending on the start time of the soundings. The start time of the soundings is 45 to $75 \mathrm{~min}$ prior to the reporting time at 00:00, 06:00, 12:00, and 18:00 UTC. There- fore the corresponding values from 23:00, 05:00, 11:00, and 17:00 UTC of the simulated data were selected. The observations are flagged with quality status flags, which were derived by the use of four different methods to calculate the height of the PBL (Beyrich and Leps, 2012). From both data sets the values with observation quality flag "good" were extracted. For comparison both values were related to ground height, because real elevation is $112 \mathrm{~m}$ while the model height is $63 \mathrm{~m}$.

Figure 12 shows the frequency distribution of boundary layer heights from model and observation by launch time and season. The classes refer to the model levels.

Both frequency distributions show the shift to higher values during noon for all seasons. In general the accordance of the distributions is highest for the noon soundings. The tendency to wider spread distributions at 18:00 UTC is given for both data sets. Most of the 16 distribution functions of simulated values show a bimodal shape, while the observed value functions have clear maxima, for non-noon soundings mostly beneath $213 \mathrm{~m}$. The simulated frequencies in the lowest five 

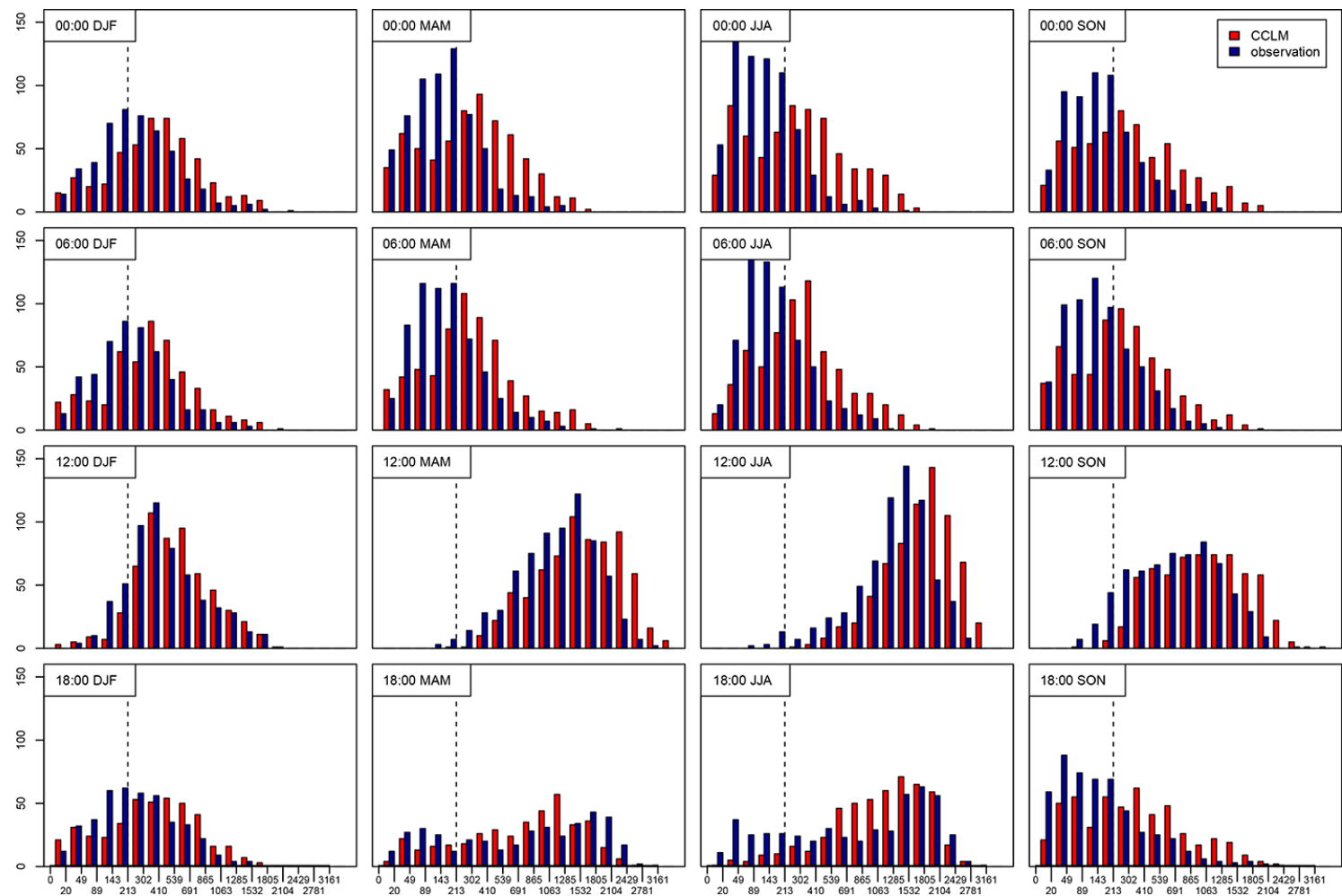

Figure 12. Frequency distribution of the planetary boundary layer height [m] of coastDat2-CCLM and observation from 2003 to 2012.

Table 2. Statistical parameters of the comparison between observed and simulated PBL height, split for sounding times in column 3 to 6 , and seasons in rows according to the abbreviation in column 2. Listed are the number and the median of used observed values (median $\mathrm{O}$ ), median of simulated values (median $\mathrm{S}$ ), and the differences of the medians. Unit of the last three variables is $\mathrm{m}$.

\begin{tabular}{|c|c|c|c|c|c|}
\hline & & 00:00 & 06:00 & $12: 00$ & 18:00 \\
\hline \multirow{4}{*}{ number } & DJF & 490 & 647 & 678 & 598 \\
\hline & MAM & 486 & 630 & 665 & 633 \\
\hline & JJA & 574 & 700 & 690 & 641 \\
\hline & SON & 424 & 396 & 505 & 509 \\
\hline \multirow{4}{*}{ median $\mathrm{O}$} & DJF & 220 & 136 & 98 & 127 \\
\hline & MAM & 202 & 136 & 125 & 124 \\
\hline & JJA & 384 & 1166 & 1310 & 661 \\
\hline & SON & 232 & 829 & 917 & 109 \\
\hline \multirow{4}{*}{ median $\mathrm{S}$} & DJF & 356 & 258 & 258 & 258 \\
\hline & MAM & 356 & 258 & 258 & 258 \\
\hline & JJA & 475 & 1409 & 1669 & 964 \\
\hline & SON & 356 & 778 & 1174 & 258 \\
\hline \multirow{4}{*}{ difference } & DJF & 136 & 122 & 160 & 131 \\
\hline & MAM & 154 & 122 & 133 & 134 \\
\hline & JJA & 91 & 243 & 359 & 303 \\
\hline & SON & 124 & -51 & 257 & 149 \\
\hline
\end{tabular}

model levels (in the height of $213 \mathrm{~m}$ ) are clearly lower than the observations.

In Table 2 the numbers of good-flagged deduced heights of PBL are listed per season and sounding time, the according medians of these and the CCLM simulated heights, as well as the differences of these values are shown.

All midnight to noon simulated median values are higher than those observed within a range of 90-260 m. Only the autumn 06:00 UTC simulated value is less than the one observed. Particular high are the differences for June to August 12:00 and 18:00 UTC soundings with more then $300 \mathrm{~m}$.

\section{Conclusions}

To our knowledge, the data set described represents the longest regional reconstruction based on global atmospheric reanalyses at such a high spatial and temporal detail. It covers more than 60 years and shows good agreement with observations, although there are regions where better performance would be desirable. The comparison of the variables nearsurface air temperature, diurnal temperature range, precipitation, cloud cover, near-surface wind speed, and height of the planetary boundary layer with observations indicate on exemplary the quality of the data set. The main advantages of the data set are the huge number of available consistent variables for the entire European continent over the entire time period of 1948-2012. 
The data of the atmospheric part of coastDat2, coastDat2CCLM, (Geyer and Rockel, 2013) are downloadable from doi:10.1594/WDCC/coastDat-2_COSMO-CLM.

Acknowledgements. The CCLM is the community model of the German climate research (www.clm-community.eu). The German Climate Computing Center (DKRZ) provided the computer hardware for the Limited Area Modelling simulations in the project "Regional Atmospheric Modelling". The NCEP/NCAR1 reanalysis data was provided by the National Center for Atmospheric Research (NCAR). Thanks to the ENSEMBLES group for updating the E-OBS data set according to newest findings, to the CRU crew providing the CRU time series, GPCC and DWD for allowing us to use their data. We thank the UK Met office for providing the wind measurements at Buoy K1 station number 62029. The Athos buoy data are available via the POSEIDON Operational Oceanography System, Hellenic Centre for Marine Research (http://www.poseidon.hcmr.gr). We thank Frank Beyrich for providing height of boundary layer data from Deutscher Wetterdienst for Lindenberg. Additionally we want to thank the providers of the external data sets (cited in detail by Smiatek et al., 2008): the FAO for soil-types data, and USGS for the orography, and Global ecosystem data. Last but not least we want to thank the both reviewers which helped with their comments and suggestions to improve the manuscript.

The service charges for this open access publication have been covered by a Research Centre of the Helmholtz Association.

Edited by: G. König-Langlo

\section{References}

Baldauf, M., Seifert, A., Förstner, J., Majewski, D., Raschendorfer, M., and Reinhardt, T.: Operational Convective-Scale Numerical Weather Prediction with the COSMO Model: Description and Sensitivities, Mon. Weather Rev., 139, 3887-3905, doi:10.1175/MWR-D-10-05013.1, 2011.

Beyrich, F. and Leps, J.: An operational mixing height data set from routine radiosoundings at Lindenberg: Methodology, Meteorol. Z., 21, 337-348, doi:10.1127/0941-2948/2012/0333, 2012.

Bromwich, D. H., Bai, L., and Bjarnason, G. G.: High-Resolution Regional Climate Simulations over Iceland Using Polar MM5*, Mon. Weather Rev., 133, 3527-3547, doi:10.1175/MWR3049.1, 2005.

Christensen, J. and Christensen, O.: A summary of the PRUDENCE model projections of changes in European climate by the end of this century, Clim. Change, 81, 7-30, doi:10.1007/s10584-0069210-7, 2007.

Davies, H. C.: A lateral boundary formulation for multi-level prediction models, Q. J. Roy. Meteor. Soc., 102, 405-418, doi:10.1002/qj.49710243210, 1976.

Denis, B., Laprise, R., Caya, D., and Cote, J.: Downscaling ability of one-way nested regional climate models: the Big-Brother Experiment, Clim. Dynam., 18, 627-646, doi:10.1007/s00382001-0201-0, 2002.
Dietzer, B.: Berechnung von Gebietsniederschlagshöhen nach dem Verfahren REGNIE., Deutscher Wetterdienst - Hydrometeorologie, Offenbach, 2000.

Doms, G., J., F., Heise, E., Herzog, H.-J., Mrionow, D., Raschendorfer, M., Reinhart, T., Ritter, B., Schrodin, R., Schulz, J.-P., and Vogel, G.: A Description of the Nonhydrostatic Regional COSMO Model. Part II: Physical Parameterization, Tech. Rep., Deutscher Wetterdienst, available at: http://www.cosmo-model.org/content/model/documentation/ core/cosmoPhysParamtr.pdf (last access: 20 March 2014), 2011.

Eaton, B., Gregory, Jonathan andDrach, B., Taylor, K., and Hankin, S.: NetCDF Climate and Forecast (CF) Metadata Conventions, Version 1.4, available at: https://github.com/cf-convention/cf-documents/blob/master/ cf-conventions/1.4/cf-conventions.pdf?raw=true (last access: 20 March 2014), 2009.

Einarsson, M. A.: Climate of Iceland, in: World survey of climatology, Climates of the Oceans, Chap. 7, 15 pp. 673-697, Else, Amsterdam, 1984.

Feser, F., Weisse, R., and von Storch, H.: Multi-decadal Atmospheric Modeling for Europe Yields Multi-purpose Data, EOS Transactions, 82, 305-310, doi:10.1029/01EO00176, 2001.

Geyer, B. and Rockel, B.: coastDat-2 COSMO-CLM., World Data Center for Climate. CERA-DB "coastDat-2_COSMO-CLM", available at: http://cera-www.dkrz.de/WDCC/ui/Compact.jsp? acronym=coastDat-2_COSMO-CLM (last access: 20 March 2014), 2013.

Haylock, M. R., Hofstra, N., Tank, A. M. G. K., Klok, E. J., Jones, P. D., and New, M.: A European daily high-resolution gridded data set of surface temperature and precipitation for 1950-2006, J. Geophys. Res., 113, D20119, doi:10.1029/2008JD010201, 2008.

Jacob, D., Hurk, B. J. J. V. D., Andræ, U., Elgered, G., Fortelius, C., Graham, L. P., Jackson, S. D., Karstens, U., Köpken, C., Lindau, R., Podzun, R., Rockel, B., Rubel, F., Sass, B. H., Smith, R. N. B., and Yang, X.: A comprehensive model intercomparison study investigating the water budget during the BALTEX-PIDCAP period, Meteorol. Atmos. Phys., 77, 19-44, 2001.

Jones, P. and Harris, I.: CRU Time Series (TS) high resolution gridded data version 3.10, NCAS British Atmospheric Data Centre, 2011.

Jung, M., Vetter, M., Herold, M., Churkina, G., Reichstein, M., Zaehle, S., Cias, P., Viovy, N., Bondeau, A., Chen, Y., Trusilova, K., Feser, F., and Heimann, M.: Uncertainties of modeling gross primary productivity over Europe: A systematic study on the effects of using different drivers and terrestrial biosphere models, Global Biogeochem. Cy., 21, GB4021, doi:10.1029/2006GB002915, 2007.

Kalnay, E., Kanamitsu, M., Kistler, R., Collins, W., Deaven, D., Gandin, L., Iredell, M., Saha, S., White, G., Woollen, J., Zhu, Y., Chelliah, M., Ebisuzaki, W., Higgins, W., Janowiak, J., Mo, K. C., Ropelewski, C., Wang, J., Leetmaa, A., Reynolds, R., Jenne, R., and Joseph, D.: The NCEP/NCAR 40-year reanalysis project, B. Am. Meteorol. Soc., 77, 437-471, available at: http://rda.ucar.edu/datasets/ds090.0/docs/ bams/bams1996mar/bamspapr-bm.pdf (last access: 20 March 2014), 1996. 
Kistler, R., Kalnay, E., Collins, W., Saha, S., White, G., Woollen, J., Chelliah, M., Ebisuzaki, W., Kanamitsu, M., Kousky, V., van den Dool, H., Jenne, R., and Fiorino, M.: The NCEP-NCAR 50year reanalysis: Monthly means CD-ROM and documentation, B. Am. Meteorol. Soc., 82, 247-267, 2001.

Kothe, S., Lüthi, D., and Ahrens, B.: Analysis of the West African Monsoon system in the regional climate model COSMO-CLM, Int. J. Climatol., 34, 481-493, doi:10.1002/joc.3702, 2014.

Müller, B.: Eine regionale Klimasimulation für Europa zur Zeit des späten Maunder-Minimums 16751705, Ph.D. thesis, University of Hamburg, available at: $\quad$ http://www.hzg.de/imperia/md/content/gkss/zentrale_ einrichtungen/bibliothek/berichte/gkss_2004_2.pdf (last access: 20 March 2014), 2003.

Rockel, B. and Woth, K.: Extremes of near-surface wind speed over Europe and their future changes as estimated from an ensemble of RCM simulations, Clim. Change, 81, 267-280, 2007.

Rockel, B., Will, A., and Hense, A.: The Regional Climate Model COSMO-CLM (CCLM), Meteorol. Z., 17, 347-348, 2008.

Rudolf, B., Becker, A., Schneider, U., Meyer-Christoffer, A., and Ziese, M.: GPCC Status Report December 2010 (On the most recent gridded global data set issued in fall 2010 by the Global Precipitation Climatology Centre (GPCC)), GPCC Status Report, available at: http://www.dwd.de/bvbw/generator/DWDWWW/ Content/Oeffentlichkeit/KU/KU4/KU42/en/Reports_ _Publications/GPCC_status_report_2010,templateId=raw, property=publicationFile.pdf/GPCC_status_report_2010.pdf (last access: 20 March 2014), 2010.

Schrodin, R. and Heise, E.: The multi-layer-version of the DWD soil model TERRA/LM, Consortium for Small-Scale Modelling (COSMO) Tech. Rep., 2, 16 pp., 2001.

Schättler, U.: A Description of the Nonhydrostatic Regional COSMO-Model Part V: Preprocessing: Initial and Boundary Data for the COSMO-Model, Tech. Rep., Deutscher Wetterdienst, available at: http://www.cosmo-model.org/content/model/ documentation/core/cosmoInt2lm.pdf (last access: 20 March 2014), 2013.

Smiatek, G., Rockel, B., and Schättler, U.: Time invariant data preprocessor for the climate version of the COSMO model (COSMO-CLM), Meteorol. Z., 17, 395-405, doi:10.1127/09412948/2008/0302, 2008.

Sotillo, M. G., Ratsimandresy, A. W., Carretero, J. C., Bentamy, A., Valero, F., and González Rouco, F.: A high-resolution 44-year atmospheric hindcast for the Mediterranean Basin: contribution to the regional improvement of global reanalysis, Clim. Dynam., 25, 219-236, doi:10.1007/s00382-005-0030-7, 2005.
Steppeler, J., Doms, G., Schättler, U., Bitzer, H., Gassmann, A., Damrath, U., and Gregoric, G.: Meso-gamma scale forecasts using the nonhydrostatic model LM, Meteorol. Atmos. Phys., 82, 75-96, doi:10.1007/s00703-001-0592-9, 2003.

Stull, R. B.: An Introduction to Boundary Layer Meteorology, Atmospheric Sciences Library, Vol. 13, Springer Netherlands, 1988.

Tiedtke, M.: A Comprehensive Mass Flux Scheme For Cumulus Parameterization In Large-scale Models, Mon. Weather Rev., 117, 1779-1800, 1989.

US Geological Survey: Global Digital Elevation Model (GTOPO30), Tech. Rep., EROS Data Center Distributed Active Archive Center (EDC DAAC), 2004.

van den Besselaar, E. J. M., Haylock, M. R., van der Schrier, G., and Tank, A. M. G. K.: A European Daily High-resolution Observational Gridded Data set of Sea Level Pressure, J. Geophys. Res., 116, D11110, doi:10.1029/2010JD015468, 2011.

Vetter, M., Churkina, G., Jung, M., Reichstein, M., Zaehle, S., Bondeau, A., Chen, Y., Ciais, P., Feser, F., Freibauer, A., Geyer, R., Jones, C., Papale, D., Tenhunen, J., Tomelleri, E., Trusilova, K., Viovy, N., and Heimann, M.: Analyzing the causes and spatial pattern of the European 2003 carbon flux anomaly using seven models, Biogeosciences, 5, 561-583, doi:10.5194/bg-5561-2008, 2008.

von Storch, H., Langenberg, H., and Feser, F.: A Spectral Nudging Technique for Dynamical Downscaling Purposes, Mon. Weather Rev., 128, 3664-3673, doi:10.1175\%2F15200493\%282000\%29128\%3C3664\%3AASNTFD\%3E2.0.CO\%3 B2, 2000.

Weisse, R., von Storch, H., Callies, U., Chrastansky, A., Feser, F., Grabemann, I., Günther, H., Winterfeldt, J., Woth, K., and Pluess, A.: Regional Meteorological-Marine Reanalyses and Climate Change Projections, B. Am. Meteorol. Soc., 90, 849-860, doi:10.1175/2008BAMS2713.1, 2009.

Winterfeldt, J., Geyer, B., and Weisse, R.: Using QuikSCAT in the added value assessment of dynamically downscaled wind speed, Int. J. Climatol., 31, 1028-1039, doi:10.1002/joc.2105, 2010. 


\section{Appendix A}

Table A1. List of output variables of coastDat2 data set. The time series published by Geyer and Rockel (2013) are marked in column "ts/fix" with a cross. Time independent variables are labeled with " $\mathrm{f}$ " and "c" and were merged in the files coastDat2_COSMO-CLM_fx and coastDat2_COSMO-CLM_cl, respectively. The latter are climatological CCLM input data produced by PEP.

\begin{tabular}{|c|c|c|c|c|c|}
\hline & Variable name & Unit & Long name & Standard name & ts/fix \\
\hline 1 & AEVAP_S & $\mathrm{kg} \mathrm{m}^{-2}$ & surface evaporation & water_evaporation_amount & $\mathrm{x}$ \\
\hline 2 & ALB_RAD & 1 & surface albedo & surface_albedo & $\mathrm{x}$ \\
\hline 3 & ALHFL_S & $\mathrm{W} \mathrm{m}{ }^{2}$ & av. surface latent heat flux & surface_downward_latent_heat_flux & $\mathrm{x}$ \\
\hline 4 & ALWD_S & $\mathrm{W} \mathrm{m}^{2}$ & downward long wave radiation at the surface & - & $\mathrm{x}$ \\
\hline 5 & ALWU_S & $\mathrm{W} \mathrm{m}^{2}$ & upward long wave radiation at the surface & - & $\mathrm{x}$ \\
\hline 6 & APAB_S & $\mathrm{W} \mathrm{m} \mathrm{m}^{2}$ & av. surface photosynthetic active radiation & $\begin{array}{l}\text { surface_downwelling_photosynthetic } \\
\text { _radiative_flux_in_air }\end{array}$ & $\mathrm{x}$ \\
\hline 7 & ASHFL_S & $\mathrm{W} \mathrm{m}{ }^{2}$ & av. surface sensible heat flux & surface_downward_sensible_heat_flux & $\mathrm{x}$ \\
\hline 8 & ASOB_S & $\mathrm{W} \mathrm{m}{ }^{2}$ & av. surface net downward shortwave radiation & surface_net_downward_shortwave_flux & $\mathrm{x}$ \\
\hline 9 & ASOB_T & $\mathrm{W} \mathrm{m}^{2}$ & av. TOA net downward shortwave radiation & net_downward_shortwave_flux_in_air & $\mathrm{x}$ \\
\hline 10 & ASOD_T & $\mathrm{W} \mathrm{m} \mathrm{m}^{2}$ & av. solar downward radiation at top & - & $\mathrm{x}$ \\
\hline 11 & ASWDIFD_S & $\mathrm{W} \mathrm{m}^{2}$ & diffuse downward sw radiation at the surface & - & $\mathrm{x}$ \\
\hline 12 & ASWDIFU_S & $\mathrm{W} \mathrm{m}^{2}$ & diffuse upward sw radiation at the surface & - & $\mathrm{x}$ \\
\hline 13 & ASWDIR_S & $\mathrm{W} \mathrm{m}^{2}$ & direct downward sw radiation at the surface & - & $\mathrm{x}$ \\
\hline 14 & ATHB_S & $\mathrm{W} \mathrm{m}^{2}$ & av. surface net downward long wave radiation & $\begin{array}{l}\text { surface_net_downward_long } \\
\text { wave_flux }\end{array}$ & $\mathrm{x}$ \\
\hline 15 & ATHB_T & $\mathrm{W} \mathrm{m} \mathrm{m}^{2}$ & av. TOA outgoing long wave radiation & net_downward_long wave_flux_in_air & $\mathrm{x}$ \\
\hline 16 & AUMFL_S & $\mathrm{Pa}$ & av. eastward stress & surface_downward_eastward_stress & $\mathrm{x}$ \\
\hline 17 & AVMFL_S & $\mathrm{Pa}$ & av. northward stress & surface_downward_northward_stress & $\mathrm{x}$ \\
\hline 18 & CAPE_CON & $\mathrm{J} \mathrm{kg}^{-1}$ & specific convectively avail. potential energy & $\begin{array}{l}\text { atmosphere_specific_convective_available } \\
\text { _potential_energy }\end{array}$ & $\mathrm{x}$ \\
\hline 19 & $\mathrm{CLCH}$ & 1 & high cloud cover & cloud_area_fraction_in_atmosphere_layer & \\
\hline 20 & CLCL & 1 & low cloud cover & cloud_area_fraction_in_atmosphere_layer & \\
\hline 21 & CLCM & 1 & medium cloud cover & cloud_area_fraction_in_atmosphere_layer & \\
\hline 22 & CLCT & 1 & total cloud cover & cloud_area_fraction & $\mathrm{x}$ \\
\hline 23 & DURSUN & $s$ & duration of sunshine & duration_of_sunshine & $\mathrm{x}$ \\
\hline 24 & FC & $1 \mathrm{~s}^{-1}$ & coriolis parameter & coriolis_parameter & $\mathrm{f}$ \\
\hline 25 & FIS & $\mathrm{m}^{2} \mathrm{~s}^{-2}$ & surface geopotential & surface_geopotential & $\mathrm{f}$ \\
\hline 26 & FOR_D & - & ground fraction covered by deciduous forest & - & $\mathrm{f}, \mathrm{c}$ \\
\hline 27 & FOR_E & - & ground fraction covered by evergreen forest & - & $\mathrm{f}, \mathrm{c}$ \\
\hline 28 & FR_LAND & 1 & land-sea fraction & land_area_fraction & $\mathrm{f}, \mathrm{c}$ \\
\hline 29 & H_SNOW & $\mathrm{m}$ & thickness of snow & surface_snow_thickness & $\mathrm{x}$ \\
\hline 30 & HBAS_CON & $\mathrm{m}$ & height of convective cloud base & convective_cloud_base_altitude & \\
\hline 31 & HHL & $\mathrm{m}$ & height & altitude & $\mathrm{f}$ \\
\hline 32 & HMO3 & $\mathrm{Pa}$ & air pressure at ozone maximum & air_pressure & \\
\hline 33 & HPBL & $\mathrm{m}$ & Height of boundary layer & - & $\mathrm{x}$ \\
\hline 34 & HSURF & $\mathrm{m}$ & surface height & surface_altitude & $\mathrm{f}, \mathrm{c}$ \\
\hline 35 & HTOP_CON & $\mathrm{m}$ & height of convective cloud top & convective_cloud_top_altitude & \\
\hline 36 & HZEROCL & $\mathrm{m}$ & height of freezing level & freezing_level_altitude & \\
\hline 37 & LAI & 1 & leaf area index & leaf_area_index & \\
\hline 37 & LAI_MN & 1 & leaf area index resting period & leaf_area_index_resting_period & $\mathrm{c}$ \\
\hline 37 & LAI_MX & 1 & leaf area index vegetation period & leaf_area_index_vegetation_period & $\mathrm{c}$ \\
\hline 38 & MFLX_CON & $\mathrm{kg} \mathrm{m}^{-2} \mathrm{~s}^{-1}$ & convective mass flux density & atmosphere_convective_mass_flux & \\
\hline 39 & $\mathrm{P}$ & $\mathrm{Pa}$ & pressure & air_pressure & \\
\hline 40 & PLCOV & 1 & vegetation area fraction & vegetation_area_fraction & \\
\hline 41 & PLCOV_MN & 1 & vegetation area fraction resting period & vegetation_area_fraction_resting_period & $\mathrm{c}$ \\
\hline 42 & PLCOV_MX & 1 & vegetation area fraction vegetation period & vegetation_area_fraction_vegetation_period & d $c$ \\
\hline 43 & PMSL & $\mathrm{Pa}$ & mean sea level pressure & air_pressure_at_sea_level & $\mathrm{x}$ \\
\hline 44 & $\mathrm{PP}$ & $\mathrm{Pa}$ & deviation from reference pressure & $\begin{array}{l}\text { difference_of_air_pressure_from_model } \\
\text { _reference }\end{array}$ & \\
\hline 45 & PS & $\mathrm{Pa}$ & surface pressure & surface_air_pressure & $\mathrm{x}$ \\
\hline 46 & QC & $\mathrm{kg} \mathrm{kg}^{-1}$ & specific cloud liquid water content & mass_fraction_of_cloud_liquid_water_in_ai & \\
\hline 47 & QI & $\mathrm{kg} \mathrm{kg}^{-1}$ & specific cloud ice content & mass_fraction_of_cloud_ice_in_air & \\
\hline 48 & $\mathrm{QR}$ & $\mathrm{kg} \mathrm{kg}^{-1}$ & specific rain content & mass_fraction_of_rain_in_air & \\
\hline 49 & QS & $\mathrm{kg} \mathrm{kg}^{-1}$ & specific snow content & mass_fraction_of_snow_in_air & \\
\hline 50 & QV & $\mathrm{kg} \mathrm{kg}^{-1}$ & specific humidity & specific_humidity & \\
\hline
\end{tabular}


Table A1. Continued.

\begin{tabular}{|c|c|c|c|c|c|}
\hline & Variable name & Unit & Long name & Standard name & ts/fix \\
\hline 51 & QV_2M & $\mathrm{kg} \mathrm{kg}^{-1}$ & $2 \mathrm{~m}$ specific humidity & specific_humidity & $\mathrm{x}$ \\
\hline 52 & QV_S & $\mathrm{kg} \mathrm{kg}^{-1}$ & surface specific humidity & surface_specific_humidity & \\
\hline 53 & RAIN_CON & $\mathrm{kg} \mathrm{m}^{-2}$ & convective rainfall & convective_rainfall_amount & $\mathrm{x}$ \\
\hline 54 & RAIN_GSP & $\mathrm{kg} \mathrm{m}^{-2}$ & large-scale rainfall & large_scale_rainfall_amount & $\mathrm{x}$ \\
\hline 55 & RELHUM_2M & $\%$ & $2 \mathrm{~m}$ relative humidity & relative_humidity & $\mathrm{x}$ \\
\hline 56 & RLAT & $\circ$ & latitude & latitude & \\
\hline 57 & RLON & $\circ$ & longitude & longitude & \\
\hline 58 & ROOTDP & $\mathrm{m}$ & root depth & root_depth & $\mathrm{c}$ \\
\hline 59 & RUNOFF_G & $\mathrm{kg} \mathrm{m}^{-2}$ & subsurface runoff & subsurface_runoff_amount & $\mathrm{x}$ \\
\hline 60 & RUNOFF_S & $\mathrm{kg} \mathrm{m}^{-2}$ & surface runoff & surface_runoff_amount & $\mathrm{x}$ \\
\hline 61 & SNOW_CON & $\mathrm{kg} \mathrm{m}^{-2}$ & convective snowfall & convective_snowfall_amount & $\mathrm{x}$ \\
\hline 62 & SNOW_GSP & $\mathrm{kg} \mathrm{m}^{-2}$ & large-scale snowfall & large_scale_snowfall_amount & $\mathrm{x}$ \\
\hline 63 & SNOWLMT & $\mathrm{m}$ & height of the snow fall limit in $\mathrm{m}$ above sea level & altitude & \\
\hline 64 & SOBS_RAD & $\mathrm{W} \mathrm{m}^{2}$ & surface net downward shortwave radiation & surface_net_downward_shortwave_flux & \\
\hline 65 & SOILTYP & 1 & soil type & soil_type & $\mathrm{f}, \mathrm{c}$ \\
\hline 66 & SSO_GAMMA & - & anisotropy of sub-grid scale orography & - & $\mathrm{f}, \mathrm{c}$ \\
\hline 67 & SSO_SIGMA & - & mean slope of sub-grid scale orography & - & $\mathrm{f}, \mathrm{c}$ \\
\hline 68 & SSO_STDH & $\mathrm{m}$ & standard deviation of height & standard_deviation_of_height & $\mathrm{f}, \mathrm{c}$ \\
\hline 69 & SSO_THETA & $\circ$ & angle between principal axis of orography and east & - & $\mathrm{f}, \mathrm{c}$ \\
\hline 70 & $\mathrm{~T}$ & $\mathrm{~K}$ & temperature & air_temperature & \\
\hline 71 & T_2M & $\mathrm{K}$ & $2 \mathrm{~m}$ temperature & air_temperature & $\mathrm{x}$ \\
\hline 72 & T_2M_AV & $\mathrm{K}$ & $2 \mathrm{~m}$ temperature & air_temperature & $\mathrm{x}$ \\
\hline 73 & T_CL & $\mathrm{K}$ & deep soil temperature & soil_temperature & $\mathrm{c}$ \\
\hline 74 & T_G & $\mathrm{K}$ & grid mean surface temperature & surface_temperature & \\
\hline 75 & $\mathrm{~T} \_\mathrm{S}$ & $\mathrm{K}$ & soil surface temperature & - & $\mathrm{x}$ \\
\hline 76 & T_SNOW & $\mathrm{K}$ & snow surface temperature & surface_temperature_where_snow & \\
\hline 77 & T_SO & $\mathrm{K}$ & soil temperature & soil_temperature & \\
\hline 78 & TD_2M & $\mathrm{K}$ & $2 \mathrm{~m}$ dew point temperature & dew_point_temperature & $\mathrm{x}$ \\
\hline 79 & TD_2M_AV & $\mathrm{K}$ & $2 \mathrm{~m}$ dew point temperature & dew_point_temperature & $\mathrm{x}$ \\
\hline 80 & TDIV_HUM & $\mathrm{kg} \mathrm{m}^{-2}$ & atmosphere water divergence & $\begin{array}{l}\text { change_over_time_in_atmospheric_water } \\
\text { _content_due_to_advection }\end{array}$ & \\
\hline 81 & THBS_RAD & $\mathrm{W} \mathrm{m}^{2}$ & surface net downward long wave radiation & $\begin{array}{l}\text { surface_net_downward_long } \\
\text { wave_flux }\end{array}$ & \\
\hline 82 & TKE_CON & $\mathrm{J} \mathrm{kg}^{-1}$ & convective turbulent kinetic energy & - & \\
\hline 83 & TMAX_2M & $\mathrm{K}$ & $2 \mathrm{~m}$ maximum temperature & air_temperature & $\mathrm{x}$ \\
\hline 84 & TMIN_2M & $\mathrm{K}$ & $2 \mathrm{~m}$ minimum temperature & air_temperature & $\mathrm{x}$ \\
\hline 85 & TOT_PREC & $\mathrm{kg} \mathrm{m}^{-2}$ & total precipitation amount & precipitation_amount & $\mathrm{x}$ \\
\hline 86 & TQC & $\mathrm{kg} \mathrm{m}^{-2}$ & vertical integrated cloud water & atmosphere_cloud_liquid_water_content & $\mathrm{x}$ \\
\hline 87 & TQI & $\mathrm{kg} \mathrm{m}^{-2}$ & vertical integrated cloud ice & atmosphere_cloud_ice_content & $\mathrm{x}$ \\
\hline 88 & TQV & $\mathrm{kg} \mathrm{m}^{-2}$ & precipitable water & atmosphere_water_vapor_content & $\mathrm{x}$ \\
\hline 89 & TWATER & $\mathrm{kg} \mathrm{m}^{-2}$ & total water content & atmosphere_water_content & $\mathrm{x}$ \\
\hline 90 & $\mathrm{U}$ & $\mathrm{m} \mathrm{s}^{-1}$ & U-component of wind & grid_eastward_wind & \\
\hline 91 & U_10M & $\mathrm{ms}^{-1}$ & U-component of $10 \mathrm{~m}$ wind & grid eastward wind & $\mathrm{x}$ \\
\hline 92 & $\mathrm{~V}$ & $\mathrm{~m} \mathrm{~s}^{-1}$ & V-component of wind & grid_northward_wind & \\
\hline 93 & V_10M & $\mathrm{m} \mathrm{s}^{-1}$ & $\mathrm{~V}$-component of $10 \mathrm{~m}$ wind & grid_northward_wind & $\mathrm{x}$ \\
\hline 94 & UVlat_10M & $\mathrm{ms}^{-1}$ & $\mathrm{U}$ and $\mathrm{V}$-component of $10 \mathrm{~m}$ wind & & $\mathrm{x}$ \\
\hline 95 & VGUST_CON & $\mathrm{m} \mathrm{s}^{-1}$ & maximum $10 \mathrm{~m}$ convective gust & wind_speed_of_gust & $\mathrm{x}$ \\
\hline 96 & VGUST_DYN & $\mathrm{ms}^{-1}$ & maximum $10 \mathrm{~m}$ dynamical gust & wind_speed_of_gust & $\mathrm{x}$ \\
\hline 97 & VIO3 & $\mathrm{Pa}$ & vertical integrated ozone amount & $\begin{array}{l}\text { equivalent_pressure_of_atmosphere_ozone } \\
\text { ccontent }\end{array}$ & \\
\hline 98 & VMAX_10M & $\mathrm{m} \mathrm{s}^{-1}$ & maximum $10 \mathrm{~m}$ wind speed & wind_speed_of_gust & $\mathrm{x}$ \\
\hline 99 & $\mathrm{~W}$ & $\mathrm{~ms}^{-1}$ & vertical wind velocity & upward_air_velocity & \\
\hline 100 & W_I & $\mathrm{m}$ & canopy water amount & canopy_water_amount & \\
\hline
\end{tabular}


Table A1. Continued.

\begin{tabular}{|c|c|c|c|c|c|}
\hline & Variable name & Unit & Long name & Standard name & ts/fix \\
\hline 101 & W_SNOW & $\mathrm{m}$ & surface snow amount & lwe_thickness_of_surface_snow_amount & \\
\hline 102 & W_SO & $\mathrm{m}$ & soil water content & lwe_thickness_of_moisture_content_of_soil_layer & $\mathrm{X}$ \\
\hline 103 & W_SO_ICE & $\mathrm{m}$ & soil frozen water content & lwe_thickness_of_frozen_water_content_of_soil_layer & $\mathrm{x}$ \\
\hline 104 & WDIRlat_10M & $\circ$ & & & $\mathrm{x}$ \\
\hline 105 & WSS_10M & $\mathrm{m} \mathrm{s}^{-1}$ & & wind_speed & $\mathrm{X}$ \\
\hline 106 & $\mathrm{ZO}$ & $\mathrm{m}$ & surface roughness length & surface_roughness_length & $\mathrm{X}$ \\
\hline 107 & $\mathrm{ZO}$ & $\mathrm{m}$ & backround surface roughness length & surface_roughness_length & $\mathrm{c}$ \\
\hline 108 & Z0_VEG & $\mathrm{m}$ & surface roughness length due to vegetation & surface_roughness_length_due_to_vegetation & $\mathrm{c}$ \\
\hline
\end{tabular}

